\title{
THE ROLE OF EDUCATOR IN COMMUNITY ESPECIALLY DURING PANDEMIC: RESPONDING TO THE CHANGE OF LEARNING USING ONLINE PLATFORM IN ELEMENTARY SCHOOL
}

\author{
Sylvia Samuel ${ }^{1}$, John Tampil Purba ${ }^{2}$ \\ ${ }^{1}$ Universiras Pelita Harapan \\ ${ }^{2}$ Universitas Pelita Harapan
}

Email: syl_samuel@yahoo.com,john.purba@uph.edu,

\begin{abstract}
Abstrak
Disaat Pandemi COVID-19, seluruh proses kegiatan belajar mengajar mengharuskan sekolah - sekolah untuk melakukan proses pembelajaran dari rumah atau yang di kenal dengan sebutan belajar dari rumah (BDR). Proses pembelajaran daring / online mengharuskan Pendidikan anak usia dini (Paud dan Sekolah Dasar (SD) untuk beradaptasi dengan perubahan yang terjadi di lingkungan pembelajaran yaitu dengan menggunakan Platform online untuk proses belajar mengajar. Seiring dengan adanya era Industri 4.0 perlu memperkenalkan teknologi informasi dan komunikasi (TIK) kepada masyarakan dimulai dari anak usia dini, lanjut Pendidikan di Sekolah Dasar (SD). Disaat inilah kegiatan pengabdian masyarakat ini dilakukan dengan tujuan untuk memperkenalkan kepada tenaga pengajar platform online atau alat bantu untuk proses mengajar selama pandemi serta mempersiapkan tenaga pengajar untuk dapat melakukan pengajaran secara kreatif dan inovatif mesikupn secara daring / online. Pelatihan ini bertujuan untuk melakukan standardisasi platform belajar mengajar yang digunakan oleh sekolah Gamaliel dan mentransfer ketrampilan penggunaan Ms. Teams dalam pengajaran. Pelatihan ini dihadiri oleh 10 orang tenaga pengajar dari Sekolah Gamaliel. Berdasarkan hasil dari evaluasi pelatihan, peserta terkesan dengan penggunaan plaform online secara mudah dalam pengajaran. Hasil dari pelatihan yaitu meningkatkan kemampuan tenaga pengajar dalam beradaptasi dan menggunakan fitur Ms. Teams. Tahap berikutnya proses belajar mengajar sesuai dengan taksonomi bloom sebagai berikut: 1) Mengerti dan menghafal; 2) Aplikasi; 3) Integrasi; 4) Manusia; dan 5) Bagaimana cara belajar
\end{abstract}

Kata Kunci: online learning, covid-19, Ms. Teams, indutri 4.0, teknologi

\section{PENDAHULUAN}

Dunia secara global melihat informasi dan teknologi serta pengetahuan menjadi salah satu sumber kesejahteraan bagi suatu bangsa. Nilai manusia secara sistem mengalami perubahan, menempati posisi dimana selalu ditekankan pada pengetahuan sebagai kunci faktor dari pemberdayaan sosial secara individu (Purba, 2014).
Individu dan masyarakat luas berpartisipasi dalam proses globalisasi, dimana pengetahuan sebagai salah satu kunci utama dari realisasi diri sendiri, kesuksesan dan sebagai salah satu jaminan utama kesejahteraan dalam kehidupan masyrakat. Paradigma dari ekonomi baru menekankan bukan hanya pembelajaran secara individu, tetapi juga belajar dari komunitas dan belajar dari lingkungan

Teknologi Tepat Guna 
masyarakat seperti di institusi Pendidikan, perusahaan). Menurut Clapper (2018) mengemukakan bahwa proses belajar lebih penting daripada apa yang dipelajari. Perkataan ini dapat dilihat dari beberapa sekolah di dunia yang menyatakan kebutuhan terhadap pembelajaran berdasarkan pengalaman. Sehingga proses belajar disini sangatlah penting, bagaimana cara pembelajara, bagaimana penyampaian materi. Ekonomi global telah menggantikan slogan Era Soviet yaitu belajar, belajar, belajar (Learn, learn and learn) dengan yang baru yaitu (Learn to Learn) belajar untuk belajar, sebagai salah satu kondisi untuk memenuhi permintaan dari informasi masyrakat.

Saat ini, institusi Pendidikan dari Pendidikan anak usia dini (PAUD), sekolah dasar (SD), sekolah menengah sampai Perguruan Tinggi sedang tutup sementara dikarenakan Pandemi COVID-19, karena hampir seluruh negara di dunia telah memberhentikan proses belajar secara tatap muka dan digantikan dengan proses pembelajaran secara daring / Online. Tidak ada yang dapat mengetahui secara pasti sampai kapan keadaan ini akan berlangsung, sehingga sekolah tetap harus melanjutkan keberlangsungan proses belajar mengajar secara jarak jauh. Seluruh jenjang Pendidikan di seluruh dunia terutama di Indonesia harus mencari solusi untuk menghadapi krisis ini, dan memberikan pengajaran secara adil dan berkesinambungan dalam proses belajar mengajar selama COVID-19.

Agar proses pembelajaran tetap dapat berlangsung, pemerintah Indonesia mulai sosialisasikan beberapa platform online untuk proses belajar mengajar yang dapat diakses secara gratis oleh sekolah dan orang tua murid, agar tetap dapat mengikuti proses belajar mengajar. Namun, masyarakat Indonesia banyak yang tidak siap untuk menghadapai cara pembelajaran secara daring, sehingga pihak sekolah juga mengalami banyak kesulitan untuk melanjutkan proses belajar mengajar. Beberapa hal yang menjadi kendala yang dihadapi oleh pihak orang tua murid antara lain: pihak orang tua murid mengeluh mengenai kuota internet, tidak memiliki telepon pintar untuk mengakses materi seperti video yang di unggah ke youtube, jangkauan signal yang kurang memadai, dan masih banyak hal lain yang menyebabkan proses belajar mengajar mengalami hambatan dalam pendistribusian materi kepada peserta didik.

$$
\text { Dengan memperhatikan Peraturan }
$$

Pemerintah Republik Indonesia Nomor 101 tahun 2000 tentang pendidikan dan pelatihan jabatan pegawai negeri sipil mendefinisikan Pendidikan dan Pelatihan Jabatan Pegawai yang selanjutnya disebut Diklat sebagai proses penyelenggaraan belajar mengajar dalam rangka meningkatkan kemampuan pegawai. Selanjutnya dalam Undang Undang RI Nomor 16 Tahun 2017 tentang Guru dan Dosen bahwa guru wajib memiliki kualifikasi akademik, kompetensi, sertifikat pendidik, sehat jasmani dan rohani, serta memiliki kemampuan untuk mewujudkan tujuan pendidikan nasional (UU no. 16/thn2017, Butarbutar \& Purba, 2016, Purba, 2014). Sesuai dengan Peraturan Pemerintah dimana wajib melaksanakan proses Pendidikan belajar mengajar secara kreatif berbasis kompetensi dalam hal penggunaan teknologi yang telah ditetapkan berdasarkan Menteri Pendidikan pada tahun 2007 yang lalu.

Dengan adanya tuntutan jaman di era digital dan perkembangan ilmu pengetahuan serta teknologi, bentuk dan model Pendidikan dan pelatihan akan mengalami penyesuaian dan perubahan. Perkembangan teknologi sangat cepat di seluruh aspek kehidupan. Konsep Industri 4.0 sudah diperkenalkan oleh pemerintah jerman (Rojika et al., 2017). Revolusi industri 4.0 membuat semua perusahaan secara hirarki memiliki sistem otomatis untuk mengatur sistem produksi yang memberikan fleksibilitas produksi secara masal dan juga fleksibilitas dalam produksi secara jumlah. Manfaat dari industri 4.0 untuk pabrik dapat mengurangi biaya produksi dan biaya logistik hampir sebesar 10-30\% dan biaya pengaturan kualitas sebanyak 10$20 \%$ (Rojika et al., 2017). Industri 4.0, menitik beratkan pada aspek kunci utama yaitu Informasi dan Teknologi, sehingga ini juga memberikan dampak yang besar bagi dunia Pendidikan, dimana Pendidikan melakukan transformasi dalam proses pembelajaran menggunakan teknologi sebagai alat

$$
\text { Teknologi Tepat Guna }
$$


bantu atau alat yang memfasilitasi proses belajar. Informasi teknologi sudah mulai diperkenalkan di sekolah - sekolah di seluruh Indonesia dan kepada masyarakat luas. Tapi sangat disayangkan di Indonesia masih banyak sekolah sekolah yang tidak mewajibkan mata pelajaran Teknik Informasi dan Teknologi bagi anak - anak sekolah dasar, bahkan ada beberapa sekolah dasar yang tidak memiliki fasilitas komputer bahkan internet untuk mengimplementasikan mata pelajaran Informasi Teknologi.

Setelah ditinjau dan dilakukan observasi ke sekolah Gamaliel, sekolah ini memiliki fasilitas ruang lab Komputer, tetapi kurangnya pengoptimalan fasilitas komputer tersebut. Pada saat pandemi COVID-19, ketika pemerintah menerapkan PSBB (Pembatasan sosial berskala besar), dimana semua pekerja dan peserta didik harus bekerja dari rumah (WFH) dan belajar dari rumah (BDR) sehingga pihak sekolah harus melangsungkan proses belajar mengajar secara daring / online, pada saat itu, pihak mengalami kesulitan karena tidak adanya persiapan bagi tenaga pengajar untuk melakukan proses pengajaran secara daring. Sejak bulan Maret sampai Juni 2020, sekolah Gamaliel menggunakan WHATSAPP untuk proses belajar mengajar secara daring, dan juga melakukan rekaman video singkat untuk setiap mata pelajaran, yang kemudian diunggah ke dalam Youtube, sehinggaorang tua dan peserta didik tetap dapat mengakses materi yang diajarkan setiap harinya dari youtube.

Berkaitan dengan permasalahan yang ada, maka solusi permasalahan dilakukan dengan membuat pelatihan penggunaan platform Online untuk mengatasi masalah yang dihadapi sekolah Gamaliel. Tujuan dari kegiatan pengabdian ini diantaranya memberikan pengenalan, sosialisasi dan pelatihan kepada tenaga pengajar tentang membangun sumber daya manusia (SDM) yang berguna dan penggunaan serta pemanfaatan teknologi sebagai alat bantu dalam proses belajar mengajar secara daring / online, sehingga tenaga pengajar di industri 4.0 dengan tuntutan dan perubahan jaman yang semakin cepat dapat menciptakan proses pembelajaran yang kreatif, inovatif baik secara synchronous dan asynchronous di era tatanan baru selama COVID-19. Platform online yang diajarkan untuk melangsungkan proses pembelajaran secara daring / Online adalah dengan menggunakan Microsoft Office 365 dimana seluruh kegiatan dapat terintegrasi menjadi satu melalui satu sarana dari Microsoft Office 365 yaitu A1 education for Remote learning. Proses belajar mengajar ini dapat menggunakan Microsoft Office 365 yang terintegrasi dengan aplikasi Microsoft Teams yang memudahkan pihak sekolah untuk menganalisa pembelajaran masing - masing tenaga pengajar dan peran serta anak didik dalam setiap pertemuan pembelajaran. Penggunaan aplikasi Microsoft Teams juga mempermudah para tenaga pengajar untuk membagikan tugas melalui fitur Assignment yang ada di dalamnya kepada setiap peserta didik. Fungsi dari fitur Assignment juga dapat melihat peserta didik yang telah mengerjakan dan telah kumpul, bahkan yang tidak mengerjakan, serta dapat dilakukan penilaian secara langsung dalam aplikasi tersebut, sehingga peserta didik juga mendapatkan umpan balik atau feedback dari hasil tugas yang dilakukan, dimana dapat memotivasi peserta didik untuk lebih giat lagi agar mendapatkan nilai yang lebih baik. Di dalam aplikasi TEAMS memiliki banyak fitur yang dapat dioptimalkan penggunaanya bagi tenaga pengajar, sehingga penggunaan TEAMS ini akan sangat bermanfaat bagi sekolah Gamaliel dalam proses pembelajaran secara daring / Online. Kegiatan ini bertujuan untuk memberikan ketrampilan bagi tenaga pengajar dalam penggunaan teknologi sebagai alat bantu dalam proses belajar mengajar sehingga tenaga pengajar dapat memaksimalkan penggunaannya untuk pengajaran berbasis kompetensi secara kreatif dan inovatif di sekolah Gamaliel sesuai dengan perarturan pemerintah. Selanjutnya bagi peserta didik dapat dilengkapi dengan ketrampilan dalam penggunaan teknologi yang akan menjadi bekal bagi peserta didik di masa depan sesuai dengan Fink taksonomi yaitu fondasi pengetahuan dan dimensi manusia serta pembelajaran.

\section{METODE PELAKSANAAN}

Dalam hal pencapaian tujuan tersebut di atas, ada beberapa metode yang digunakan yaitu: a. Metode pembelajaran dengan cara efektif dan menarik dengan anak-anak agar suasana menjadi nyaman dan menggembirakan sehingga mereka

$$
\text { Teknologi Tepat Guna }
$$


menjadi antusias untuk belajar dengan target bisa mengetahui aplikasi MS. Teams dengan baik hingga nanti ilmunya bisa diterapkan dalam berbagai aktivitas kehidupan sehari hari (Purba, 2016, 2020).

Memberikan pelatihan dengan Materi yang baik dan menarik kepada peserta ajar di sekolah Gamaliel Jakarta.

Metode pelaksanaan kegiatan yang dilakukan pada aktivitas pengabdian masyarakat seperti ditunjukkan pada gambar 1 berikut ini.

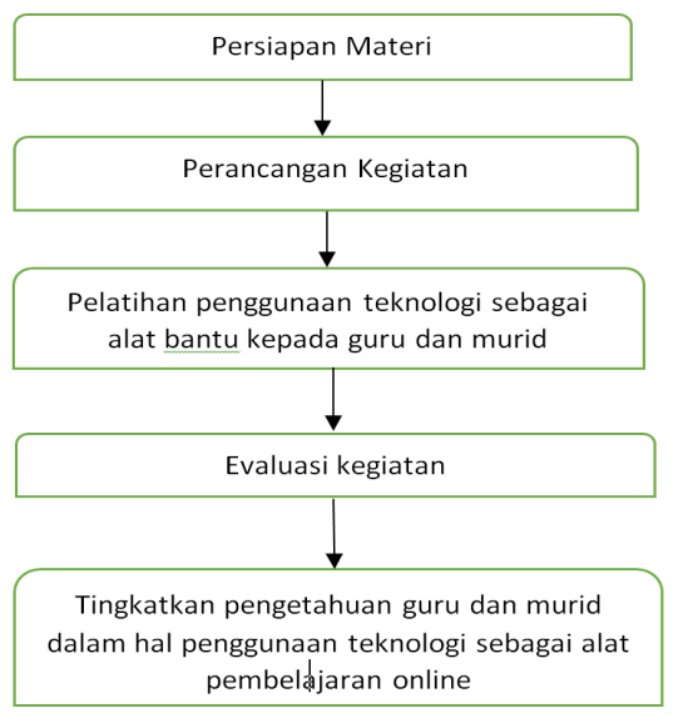

Gambar 1. Alur pengajaran dengan penggunaan Teknologi Informasi untuk proses belajar mengajar di Sekolah Gamaliel.

Kegiatan pengabdian masyarakat yang dilakukan tentang peningkatan pengetahuan guru dan murid dalam hal praktek penggunaan teknologi Komputer sebagai alat pembelajaran online yang diperlukan pada saat COVID-19 dan selama proses pembelajaran secara daring berlangsung. Kegiatan yang dilakukan adalah bertempat di TK-SD Sekolah Gamaliel yang beralamatkan di Jln. Jembatan Besi 2 No. 45 Jakarta Barat, 11320, Jakarta. Tahap pertama yang dilakukan, adalah proses persiapan dengan melakukan observasi lapangan ke sekolah Gamaliel. Setelah itu dilakukan persiapan bahan berupa perancangan program yang akan digunakan sebagai bahan pelatihan kepada guru dan murid. Materi pelatihan yang digunakan berupa slide presentasi mengenai pentingnya sumber daya manusia bagi sebuah perusahaan terutama dalam hal ini adalah sekolah (Hady, 2020), pengembangan pengetahuan yang inovatif bagi tenaga pengajar, tantangan pembelajaran di era pandemi and era tatanan baru COVID-19, dan langkah - langkah penggunaan platform online yaitu TEAMS untuk proses pembelajaran daring selama tidak diperbolehkan kegiatan belaja mengajar secara tatap muka, dan juga memperkenalkan pentingnya proses pembelajaran secara daring yaitu harus adanya interaksi dan partisipasi antara murid dan guru berdasarkan teori taksonomi Fink's (Fink, 2003).

Tahap selanjutnya yang di lakukan adalah pendistribusian dan penjelasan bahan pelatihan di ruangan kelas sekolah Gamaliel bersama tenaga pengajar dengan menggunakan laptop dan smart phone dari masing - masing tenaga pengajar. Pelatihan yang dilakukan pada tanggal 10 Juli 2020 yang dimulai dari pagi hari sampai siang hari sekitar 4 jam, dari jam 08.30 AM - 12.30 PM yang dapat dilihat pada gambar 2 .

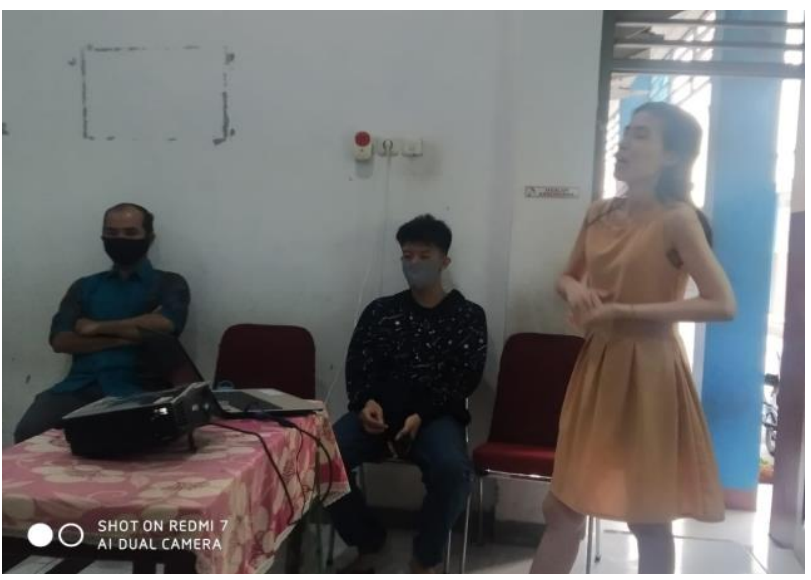

Gambar 2. Pelatihan dengan tenaga pengajar

Pelatihan selanjutnya mengenai proses pembelajaran secara daring / online dengan menggunakan teknologi selama era tatanan baru juga disosialisaikan dengan orang tua murid dan juga dilakukan pelatihan terpisah antara tenaga pengajar dan orang tua murid secara langsung dengan waktu pengajaran kurang lebih 2 jam dari jam 09.00 AM - 11.00 AM yang yang dilakukan pada hari yang berbeda dan dapat dilihat pada gambar 3 . 


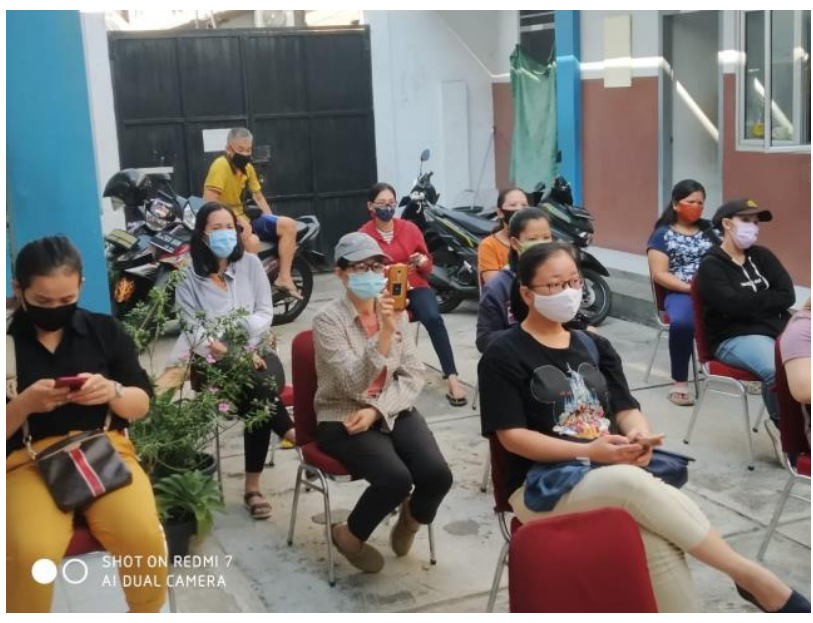

Gambar 3: Pelatihan dengan orang tua murid

Tahap yang terakhir yaitu dilakukan pengevalusian terhadap kegiatan pelatihan pengabdian masyarakat ini melalui simulasi secara langsung antara tenaga pengajar dan pelatih serta tenaga pengajar dengan orang tua murid.

\section{PELAKSANAAN DAN HASIL}

Tujuan dari kegiatan pengabdian masyarakat untuk meningkatkan pengetahuan dan ketrampilan tenaga pengajar, peserta didik serta orang tua murid dalam penggunaan platform online untuk proses belajar mengajar berbasis teknologi terutama pada saat era tatanan baru dalam dunia Pendidikan karena pandemi COVID-19. Harapan dari kegiatan pengabdian masyrakat ini, diharapkan tengaa pengajar sekolah dasar, peserta didik dan orang tua murid dapat memiliki wawasan yang lebih luas dan ketrampilan penggunaan teknologi secara lebih efektif. Khususnya bagi tenaga pengajar dapat memiliki ketrampilan mengajar secara inovatif, interaktif dan menciptakan suasana yang menyenangkan bagi para peserta didik sesuai dengan revolusi industri 4.0. Metode pelaksanaan mengikuti tahapan pembelajaran yang dikemukkan oleh Bloom sebagai berikut: 1) Pengetahuan; 2) Aplikasi; 3) Penyelesaian masalah. Selanjutnya Fink juga mengemukakan taksonomi sebagai berikut: 1) Mengerti dan menghafal; 2) Aplikasi; 3) Integrasi; 4) Manusia; dan 5) Bagaimana cara belajar (Anderson dan Krathwohl, 2001).
Selanjutnya dibagi menjadi beberapa tahap, yaitu: Tahap pertama yaitu melakukan observasi lapangan dan membuat jadwal program pelatihan

yang akan dilaksanakan berdasarkan hasil observasi terhadap kebutuhan tenaga pengajar di sekolah Gamaliel. Tahap selanjutnya yang disebut tahap pelaksanaan yaitu: a) melakukan sosialisasi proses cara pembelajaran online dengan menampilkan video singkat dari Microsoft office support dan Menteri Pendidikan Republik Indonesia; b) Pelatihan dengan memberikan pengetahuan untuk memahami dan mengembangkan teknologi sebagai alat untuk memfasilitasi dalam proses belajar mengajar. Fondasi dasar pengetahuan mengenai pentingnya sumber daya manusia sebagai aset bagi sebuah perusahaan, dan pentingnya peran tenaga pengajar atau pendidik yang selayaknya harus selalu berpikir kreatif dan invovatif mengikuti perkembangan jaman dan perubahan dalam dunia Pendidikan sehingga mampu menyesuaikan diri dengan lingkungan yang terus berkembang yang di adopsi dari taksonomi fink dalam tahap aplikasi yaitu harus berpikir kreatif, berkoordinasi dengan baik antara orang tua, murid dan rekan kerja (Fink, 2013; Rusdin, 2017). Tahap berikut adalah penggabungan antara taksonomi fink dan bloom yaitu penyelesaian masalah, Integrasi dan pengimplementasian pengetahuan yang ada serta ketrampilan yang dimiliki untuk menciptakan cara belajar yang menyenangkan. Tahap terakhir yaitu melakukan evaluasi dan follow up terhadap pelatihan yang telah dilakukan.

Pelatihan bertujuan untuk memberikan pengertian dan pemahaman cara teknis pembelajaran di industri 4.0. Pada saat pelatihan diberikan pengetahuan pembelajaran pada saat era digital yang berhubungan dengan teknologi dan terutama di saat era tatanan baru karena terkena dampak COVID-19, dimana pemerintah mengharuskan peserta didik sekolah dasar harus belajar dari rumah, jika berada di wilayah zona merah, ataupun jika orang tua peserta didik tidak memperbolehkan peserta didik untuk dating ke sekolah dikarenakan penyebaran COVID-19 yang masih terus meluas dan meningkat dalam angka penyebarannya. Kegiatan yang dilakukan dapat dilihat pada gambar 4 dan 5 yaitu materi presentasi

$$
\text { Teknologi Tepat Guna }
$$


terkait meliputi pengajaran tentang pentingnya sumber daya manusia sebagai tenaga pengajar harus memperhatikan input - proses - output, dimana hasilnya harus efektif tepat sasaran terhadap hasil capaian belajar anak didik, cara pembelajaran era baru yaitu secara daring / online, peranan guru dan orang tua sangat penting harus bekerja sama untuk membantu proses belajar mengajar anak didik agar dapat tercapai tujuan pembelajaran yang telah ditetapkan.

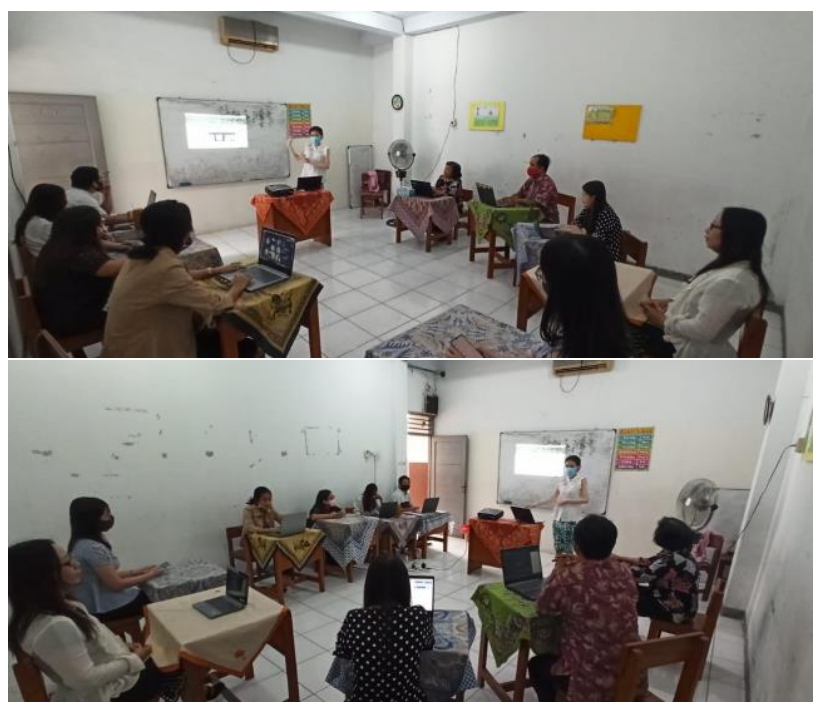

Gambar 4: Pelatihan dengan tenaga pengajar

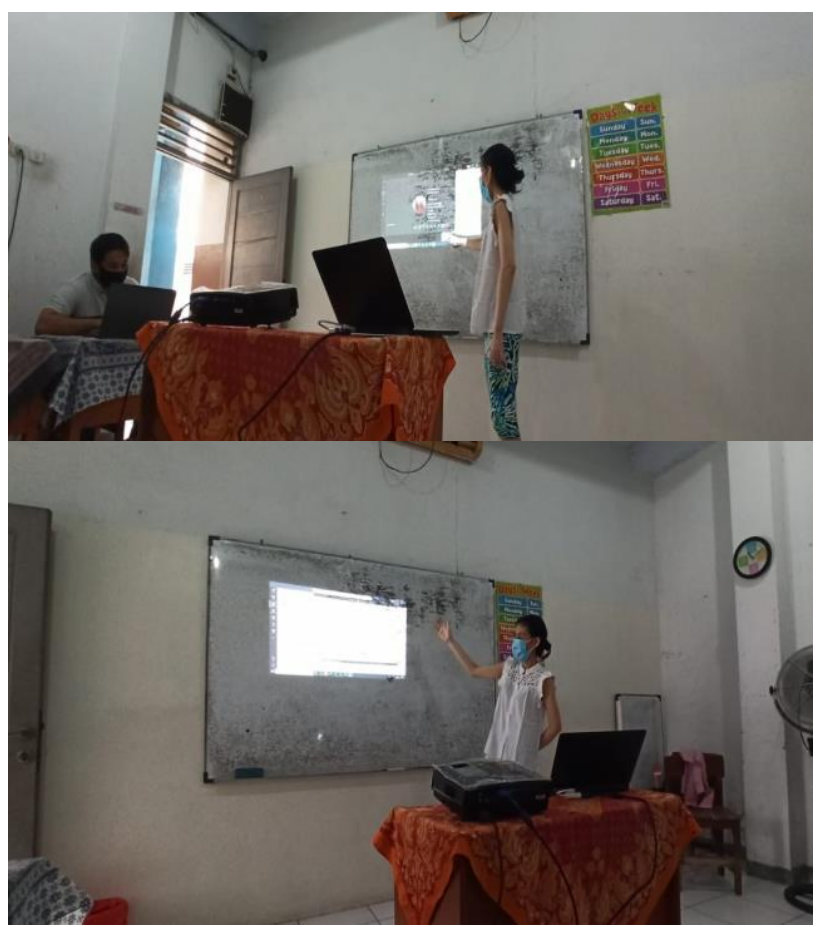

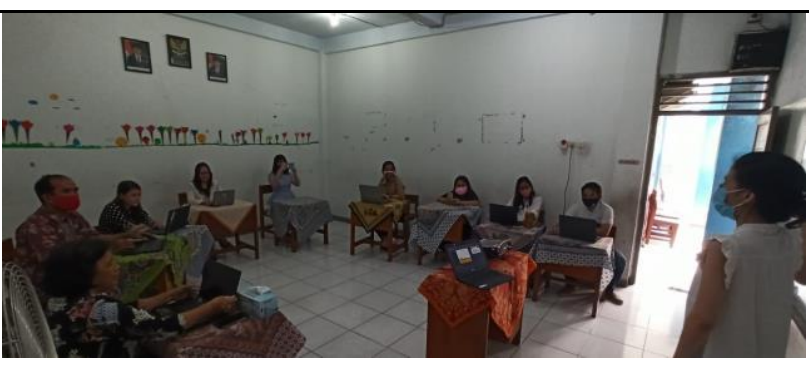

Gambar 5: Penjelasan materi

Pada saat sosialisasi cara pembelajaran online kepada tenaga pengajar yang berjumlah 10 orang. Di hari berikutnya sosiaslisasi kepada orang tua murid yang berjumlah kurang lebih 20 orang yang terdiri dari orang tua murid anak TK dan SD kelas 1 - kelas 6, dapat dilihat pada gambar 6 .

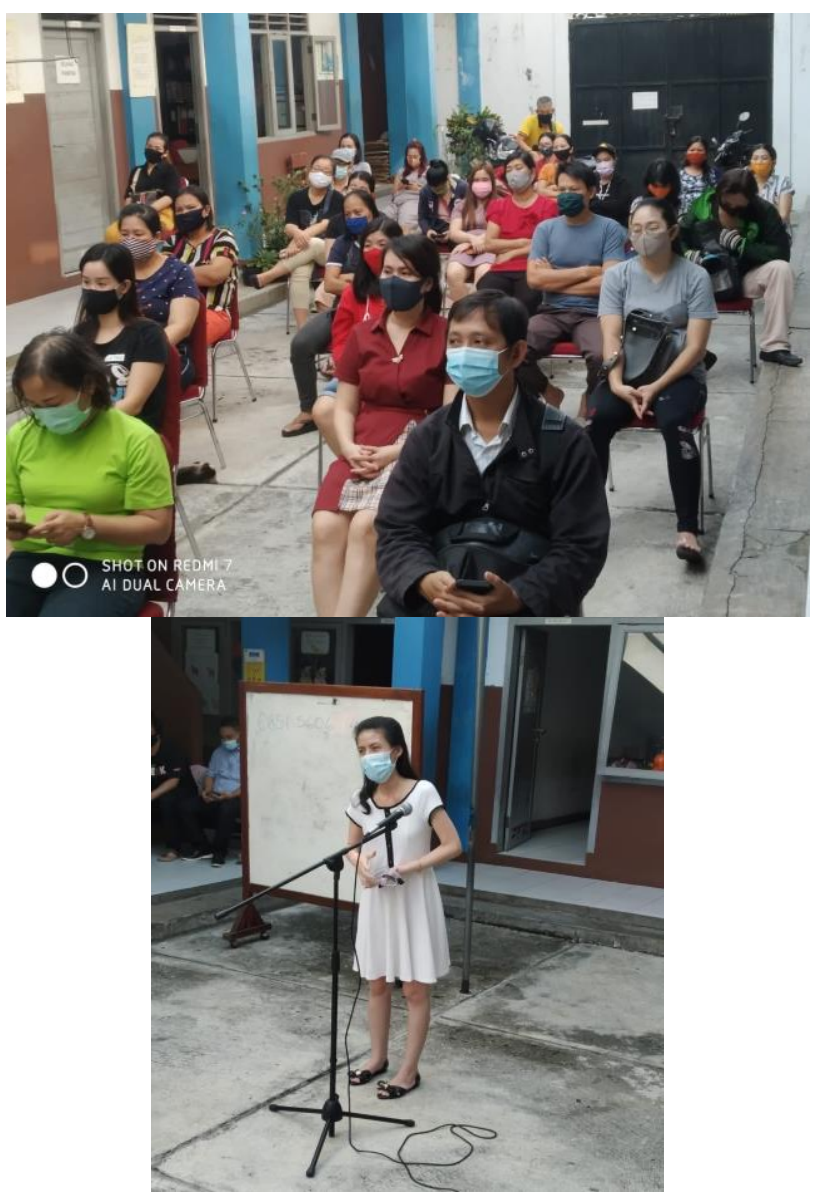

Gambar 6: Pelatihan dengan orang tua murid

Teknik pembelajaran online dengan menggunakan platform TEAMS diajarkan langkah

Teknologi Tepat Guna 
demi langkah kepada tenaga pengajar dimana diawali dengan video pembukaan, bahwa saat mengajar secara online harus diinformasikan tentang tata tertib bagi para peserta didik meskipun belajar dari rumah. Langkah berikutnya diajarkan untuk membuat group untuk kelas masing - masing proses pembelajaran. Kemudian bagaimana cara memulai pertemuan online dengan peserta didik, dilanjutkan dengan cara perekaman, sehingga kedepannya dapat di akses oleh orang tua dan peserta didik jika mereka ingin mengulang kembali atau ada hal - hal yang kurang di mengerti dalam pembelajaran baguan tersebut. Hal selanjutnya yang diajarkan yaitu bagaiman memberikan umpan balik kepada peserta didik yaitu jika dalam tatap muka adalah ulangan, ketika secara daring juga harus diberikan ulangan, ulangan yang diberikan secara online menggunakan Microsoft Forms sehingga dapat diberikan umpan balik secara langsung jika jawabannya salah, untuk anak - anak kelas 6 dapat membuat ulangan berdasarkan projek yang kemudian dapat di presentasikan degan menggunakan Microsoft power point. Kemudian juga mengajarkan tenaga pengajar terutama dalam hal berbagi materi pelajaran kepada peserta didik dan cara penggunaan papan tulis, agar dapat lebih optimal dalam pengajaran dan memberikan penjelasan kepada peserta didik, terutama untuk pelajaran matematika atau pelajaran yang membutuhkan visual.

\section{EVALUASI PELATIHAN}

Pada akhir pelatihan, keseluruhan peserta diberikan kuesioner yang berikan evaluasi terhadap pelatihan tersebut. Hasil evaluasi menunjukkan sebagai berikut. Peserta pelatihan menganggap bahwa materi yang diberikan penting dalam pelatihan (Tabel 1). Skor yang digunakan adalah skala 1 (Sangat Tidak Setuju) hingga 5 (Sangat Setuju).

Tabel 1. Pentingnya Pelatihan

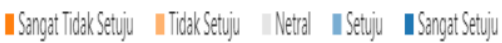

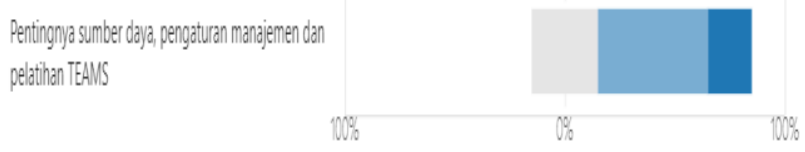

Pelatihan ini dianggap penting dalam pembahasan sumber daya dan pelatihan Ms. Teams. Materi dianggap dapat membantu menambah wawasan peserta dalam hal sumber daya sebagai tenaga pengajar dan pentingnya penggunaan alat bantu teknologi dalam proses belajar mengajar secara daring / online, yaitu Ms. TEAMS.

Para peserta pelatihan menganggap bahwa fasilitator menguasai materi dengan baik (Tabel 2). Fasilitator dianggap menguasai materi dan materi disampaikan dengan cara yang mudah dimengerti oleh peserta pelatihan.

Tabel 2. Penguasaan materi oleh fasilitator

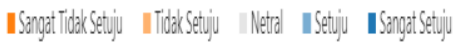

Pengussan mater dorif fasititor

Peserta menyatakan bahwa pelatihan ini memberikan manfaat bagi mereka sebagai tenaga pengar (Tabel 3). Secara spesifik, tenaga pengajar mendapatkan pengalaman baru dalam menggunakan platform online untuk mengajar dan sistem yang terintegrasi. Manfaat yang diterima dan dirasakan oleh tenaga pengajar diharapkan dapat mendukung proses kegiatan belajar mengajar di sekolah Gamaliel dalam menciptakan sistem pembelajatan yang menyenangkan, kreatif, inovatif dan bermanfaat bagi peserta didik.

Tabel 3. Manfaat pelatihan 
ISangat Tidak Setuju IITidak Setuju ||Netral IS Setuju ISangat Setuju

Manfaat Pelatihan

Sebagai penutup, peserta merasakan Microsoft Teams sangat bermanfaat, membantu dan memudahkan proses belajar mengajar selama pembelajaran daring (Tabel 4). Peserta menganggap keahlian dan kemampuan fasilitator sangat baik dan mengesankan, khususnya kemampuan dalam memberikan penjelasan secara sederhana, praktikal dan mudah dimengerti kepada para peserta.

Tabel 4. Manfaat Penggunaan Ms. Teams

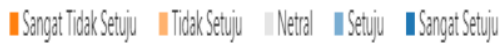

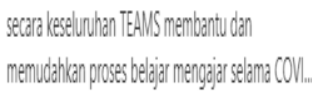

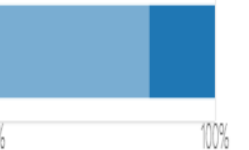

\section{KESIMPULAN DAN IMPLIKASI}

Kegiatan ini telah dilaksanakan sesuai dengan rencana. Peserta pelatihan mendapatkan manfaat dan bertambahnya wawasan setiap tenaga pengajar dalam penggunaan plaform online untuk mengajar yang dapat dikombinasikan dengan alat bantu pengajar lainnya seperti power point animation. Peserta pelatihan perlu terus memperbaharui Ms. TEAMS jika ada perbaharuan dari Microsoft Office 365. Pelatihan yang diajarkan diharapkan dapat meningkatkan ketrampilan tenaga pengajr di sekolah Gamaliel, peserta didik serta juga orang tua dalam penggunaan platform digital yang akan menjadi bekal bagi peserta didik di masa yang akan dating, dengan kecanggihan teknologi yang terus berkembang

\section{REFERENSI}

Anderson, L.W., \& Krathwohl, D. R. (Eds.). (2001). A Taxonomy for Learning, Teaching, and Assessing: A Revision of Bloom's Taxonomy of Educational Objectives. New York: Longman.

Butarbutar, F. \& Purba, J. T. (2016). Towards Educational Great and Strong Leaders: An Empirical Investigation at the Seventh-Day Adventist Schools in Indonesia. Jurnal Akuntasi dan Manajemen 2 (5).

Clapper, T. C. (2018). Capitalizing on the Most Important Part of a Learning Session: The Experience. Simulation \& Gaming, 49(1), 3-7.

Fink, D. (2013). Creating Significant Learning Experiences: An Integrated Approach to Designing College Courses. Revised and Updated Edition. UAS : Jossey-Bass.

Hady, H. (2020). Strategy Market-Based Management to Gain Sustainable Competitive Advantage How The Integrated Market Based Business Strategy Management Can Improve The Performance by Good Governance.

Nadeak, B. \& Purba, J. T. (2014). Applied Management Strategy on Human Capital in Higher Education for Faculty Development in the Dynamic Service Industry : A Case Study. Journal of Content Business in Today's Industry 1 (Vol. I), 57 -66.

Purba, J. T. (2015). Building higher education institution capacity in Indonesia through strategic faculty development. Journal of Asian Scientific Research 5 (6), 291

Purba, J. T., Rajaguguk, W.. Meranga, I. S. C. (2016). Strategic planning and foresigt on national development trough education: Nusantara nationwide evidence. Proceeding. International Conference on Nusantara Studies, Universitas Indonesia, Depok.

Purba, J.T. \& Panday, R. (2014). Usage of IT Services in Higher Education Management for Innovation Strategy. International Conference and Organization Innovation (ICOI). De La Salle University, Manila Philipines.

Purba, J. T. (2014). Strategi Pengembangan Dosen untuk Menghadapai Masyarakat Ekonomi 
Asia Tenggara: Studi Kasus. Prosiding SNEB. Faculty of Economics Achmad Yani University Bandung 2014.

Purba, J. T. (2015). Strategic Innovation Through Technology Readiness and Acceptance in Implementing ICT for Corporate Sustainability. 12th International Annual Symposium on Management 12 (12th Insyma).

Rojko, A. (2017). Industry 4.0 concept: background and overview. International Journal of Interactive Mobile Technologies (iJIM), 11(5): 7790.

Rusdin. (2017). Pendidikan dan Pelatihan Sebagai Sarana Peningkatan Kompetensi Guru di SMP Negeri 02 Linggang Bigung. Journal of Administrative Reform, 5(4): 200-212.

Peraturan Menteri Pendidikan Nasional Republik Indonesia Nomor 16 Tahun 2017 tentang Standar Kualifikasi Akademik dan Kompetensi Guru.

Peraturan Pemerintah Republik Indonesia Nomor 101 Tahun 2000 tentang Pendidikan dan Pelatihan Jabatan Pegawai Negeri Sipil Presiden Republik Indonesia. (Edisi, 2018)

Undang-Undang Republik Indonesia Nomor 14 Tahun 2005 tentang Guru dan Dosen 